\title{
Investigating Malaysian ESL Students' Writing \\ Problems on Conventions, Punctuation, and Language Use at Secondary School Level
}

\author{
Neda Ghabool (Corresponding Author) \\ School of Educational Studies, Universiti Sains Malaysia \\ 11800 Penang, Malaysia \\ Tel: 60-12-442-6106Ｅ-mail: ghabool.neda@gmail.com \\ Mariann Edwina A/P Mariadass \\ School of Educational Studies, Universiti Sains Malaysia \\ 11800 Penang, Malaysia \\ Tel: 60-12-453-7904Ｅ-mail:wina_e29@yahoo.com
}

Seyyed Hossein Kashef

School of Languages, Literacies and Translation, Universiti Sains Malaysia,

11800 Penang, Malaysia

Tel.: 60-10-509-9220Ｅ-mail address: mhkashef@gmail.com

Received: June 3, 2012 Accepted: July 8, 2012 Published: August 1, 2012

doi:10.5296/jse.v2i3.1892ＵRL: http://dx.doi.org/10.5296/jse.v2i3.1892

\begin{abstract}
This study aimed at investigating the challenges in three aspects of writing development process, namely conventions, punctuation, and language use (proper use of grammar) in secondary school level from students and teachers experiences. The data was collected from 30 ESL students as the student participants of this research, from the upper and lower secondary school, Form 1 to Form 5, and 10 teacher participants teaching English language for upper and lower secondary levels with different teaching experiences. A questionnaire and an essay examination were utilized as the instruments of the study. The findings revealed that Malaysian ESL students have problems in writing tasks, especially in language use (grammar)
\end{abstract}




\section{Macrothink}

Journal of Studies in Education

ISSN 2162-6952

2012, Vol. 2, No. 3

and punctuation. The first language interference was also very tangible in their writings. The study suggests some practical methods in order to cope with writing difficulties.

Keywords: Writing problem, Conventions, Punctuation, Language use, ESL context 


\section{Introduction}

This part discusses background of the study, statement of the problem, objectives, research questions and significance of the study.

\subsection{Background of the Study}

Individuals with writing problems may have difficulties in one or more aspects of writing skill such as proper use of grammar, conventions, punctuation, capitalization, spelling, and some of the basic and initiating aspects of writing. It is also an unpleasant piece of work for both teachers and learners in ESL classes. This subject of study is provoked not only because of the researchers' interests as teachers in the second language field, but also due to interest as researchers who are engaged in ESL writing classes in order to make a picture of what carries on in these classes. Leki (1992) claimed that ESL students complain about learning and focusing on the English word order or word forms. According to Adams and Keene (2000), cited in Al-Khasawneh (2010), today English, as the means of instruction, makes a strong contribution to education and students' efficiencies in communication are on top of institutional demands. Learners are expected to master content areas which are all taught in English, such as "mathematics, social studies, science, and business”. Such conditions have increased the profound need of teaching and learning English that can help all students cope with their academic tasks successfully. Hence, in order to handle academic tasks, ESL students need to do their best to write proficiently. Pak-TaoNg (2003) has asserted that the first idea which comes to mind is that when you think about writing, it is a part of obligatory course work. The thought seems to be true for students who should write long or short assignments. If writing is just an anxiety for students, it means they should do nothing except a chore. They are not likely to go beyond learning. Moreover, Pak-TaoNg (2003) suggested that writing consists of a lot of activities which result in understanding. Such an understanding includes a process of thinking about the topic, notes gathering, data collection, etc. which makes a reflective thought for you at the end.

\subsection{Statement of the Problem}

Writing has always been a difficult task for individuals especially for ELT practitioners. ESL teachers in Malaysia confirm the problems in writing development, especially in conventions, and punctuation. "There is therefore, a considerable need for the future generations of Malaysians to master the language. The English language had played a dominant role as a compulsory subject and medium of instruction in English medium schools which formed the backbone of the education system of pre-independence Malaysia” (Ambigapathy, 2001, cited in Voon Foo, 2007, p. 1). "Writing is such an important learning tool because it helps students to understand ideas and concepts better" (Voon Foo, 2007, p. 4). Thus, based on the importance of writing, all Malaysian policy makers have decided to emphasize it in their mainstream courses. Lack of English language proficiency is the main cause of lots of difficulties that ESL learners have in their writing tasks. Furthermore, all ESL students face more complicated problems, which may be either cultural or linguistic ones (Musa, Lie, \& Azman, 2012). These problems may create difficulty for both teachers and ESL writers, so giving attention to different aspects of variation can help ESL students adapt themselves to 
the writing standards.

According to Leki (1992), ESL students are also disappointed with difficulties in understanding word implication and meaning. It is obvious that there is a disparity between writing in the first and the second language. They are also tackling with difficulties in writing assignments, meeting deadlines as well as getting the best quality of their final writing. As a result, the current study not only concerns about some of the common writing problems among ESL students, but also suggests some solutions based on teachers and the researchers' experiences which can be helpful and supportive in developing writing skills.

\subsection{Objective of the Study}

This study had three main objectives. First, it aimed to identify the problems frequently faced by ESL students in essay writing. Second, it intended to get information about ESL teachers' feedbacks on students' writing problems and third, to suggest some possible ways to overcome the writing problems faced by Malaysian ESL students.

\subsection{Research Questions}

Based on the objectives of the study, the following questions are raised.

1. How frequent do Malaysian ESL students make mistakes in convention, punctuation, and language use?

2. What are the Malaysian ESL teachers' feedbacks on students' writing skills?

\subsection{Significance of the Study}

Since writing is a very important skill in learning and teaching a second language and due to the existence of many problematic areas in writing, this study intends to make a perception about some ESL writing problems among learners and teachers. Such perception helps teachers adapt their teaching styles according to frequent writing errors of students. Furthermore, the study also strives to offer some remedies for writing problems, paving the way for ESL learners to overcome so many difficulties they may face in their writing tasks.

\section{Literature Review}

This part explains The Importance of Writing, Writing Problems and Difficulties, Writing Problems in Malaysian Schools, Teachers' Feedback about Writing Errors, and Theoretical Framework.

\subsection{The Importance of Writing}

Al-Khasawneh (2010) argued that huge number of international contacts, regarding non-native to non-native communication and deals are carried out through English in a massive number of settings, including trade, diplomacy, tourism, journalism, science and technology, politics, etc. Therefore, the existence of competent writers and speakers of English is of a great importance for today's world. Regarding the Malaysian ESL context, "being a competent writer of English in the banking sector of Malaysia and the consequences of poorly-written business letters to clients” is what has been emphasized by Puvenesvary 
(2003, cited in Al- Khasawneh, 2010).

According to Tan and Miller (2008), writing is an intentional, social communication that involves literacy as well. Furthermore, it is taken as a means of social practices, through which patterns of participation, gender preferences, networks of support and collaboration, patterns of time use, space, tools, technology and resources are applied. In addition, through the interaction of writing with reading and written language with other semiotic modes, the symbolic meanings of literacy, and the broader social goals take place. This is exactly what literacy serves in the lives of people and institutions. Zamel (1983), a pioneer in ESL writing research, considered writing process as a "non-linear, exploratory, and generative process whereby writers discover and reformulate their ideas as they attempt to approximate meaning” (p.165).

\subsection{Writing Problems and Difficulties}

Greenhalgh (1992, cited in Tony 2001) mentioned that most frequent advice students receive about their work progress come from ESL teachers of writing. The writing task is challenging because many practical and theoretical issues are included. The ethical issues of rights and responsibilities also arise in texts. Researchers recommend that students should be supported by teachers to take control of their own writing. As a result, a responsible teacher would be a reactive reader, a person who helps students recognize and resolve writing problems. Yu (2008), contended that there are different aspects of writing, such as controlled composition model, built-in three- or five-paragraph model, basic organizational and informative assumptions, the simplified writing assignment, the assumption that supposes working without the help of each student or only with the instructor for comprehensive feedback, usage of grammar and handbooks or even lectures, and the linear composition model based on "outlining, writing, and editing”. All these aspects of the writing process have made a remarkable success in ESL classrooms.

Within this field of research which is trying to discuss writing processes, the main focus is on comparisons of writing processes included in personal writing processes, topic innovation and development, teacher opinion, student feedback, evaluation of teacher and student feedback, “conferencing”, and “instructional frameworks”. Mourtaga (2004) has confirmed that in contrast to many investigations among different studies which have been done on error correction and feedback in multiple areas, the ESL/EFL writing does not contain many studies on the recognition, categorization, and explanation of writing errors. However, some studies on ESL/EFL context have reported the fact that the first language interference is the main cause of many writing errors.

\subsection{Writing Problems in Malaysian Schools}

A review of the related studies on English language learning in Malaysian schools context indicates that the first language (Bahasa Malaysia) interferes considerably with the second language learning. For instance, Maros, Hua, and Khazriyati (2007, cited in Musa, Lie, \& Azman, 2012) examining students' language learning problems reported that Bahasa Malaysia interference is like a hindrance in the English literacy achievement among secondary school students. The error analyses and contrastive analyses in their study 
investigated all types of writing errors among 120 students in three parts of Malaysia. Then, it was claimed that using the correct form of English grammar is the main problem with Malaysian students' writing. The three recurrent grammatical errors were the misuse of articles, to be verb, and subject-verb agreements. Finally, the researchers concluded that the majority of the grammatical errors are due to the first language interference which is Malay language.

\subsection{Teachers' Feedback on Writing Errors}

Hedgcock (2005) has pointed out that the common perception that exists about teachers' corrections and scripts on writing has been considered by all experts as both error correction and feedback. He summarized that different factors can influence experts' feedback, such as proficiency level of the students, their educational prospect and needs, the writing task itself, the trainer, etc. thereby the conclusion regarding the effect of feedback in second language writing may be a "long way off".

Ramaprasad (1983) claimed that feedback is the difference between knowledge of the actual level and reference level of a factor which is used to change the differences in some ways. It is suggested that feedback is information about the students' performance value and excellence which is given to him or her. Other studies also have introduced feedback as an experience which generates self-managed learning. Gue'nette (2007) asserted that there has been an argument about the importance of teachers' feedback in research studies regarding second language writing. However, different points of view may exist on giving the remedial feedback to writing learners in order to improve their writing accurateness.

\subsection{Theoretical Framework}

It is argued that conscription decisions to the great extent depend on literacy and language acquisition theories. At present, theories of L2 acquisition and composition, or more generally, of literacy development, are certain and interestingly similar since both necessitate the progress of every person in society by language, and the associated growth of language in social communication.

Hyland (2003) mentioned that Flower and Hayes' (1981) model is the first cognitive model of writing (see Figure 1), declaring that writing is a "problem-solving, goal-directed and recursive activity". Based on three interweaving and composing elements, namely the task environment, the cognitive writing process, and long-term memory, writers move from writer-based texts to reader-based texts. The task environment consists of some outside factors related to the author as the assignment and text writing is being performed. Cognitive and mental process of writing encompasses three categories of programming, text composition, and edition. Ultimately, the author's information on a topic, his or her information about the readers and the writing strategies piled up in the memory shape the writers' long term memory.

\section{Methodology}

This part addresses the research design, procedure, participants, instruments, and data collection procedure. 


\subsection{Design}

This study followed a survey research design to examine three common writing problems among ESL students in a secondary school in Malaysia and teachers' experienced feedback towards students' writing problems. Such a design was applied to collect data randomly from 30 ESL students and 10 teachers through a questionnaire and a sample essay writing by students.

\subsection{Instruments}

The instruments used in this study were a questionnaire and an essay examination. The questionnaire was developed from Mohammad Nazim and Jalal Ahmad (2012). The questionnaire consisted of items on the types of errors that commonly occur in essay writing including conventions, punctuations, and language use. The purpose of the questionnaire was to collect data on teachers' perceptions about students' common writing errors based on their experience to investigate whether their perceptions match with students' writing errors based on a sample essay writing test. The essay examination sheet was developed to check students' probable writing errors and also to compare these committed errors with teachers' experienced feedback on students' writing problems. The topic given to the students to write their essays was, "The place I wish to visit”.

\subsection{Participants}

The participants of this research were 30 ESL students, from the upper and lower levels of secondary school, Form 1 to Form 5 and 10 participant teachers teaching English language for upper and lower secondary level. Since, each teacher had taught English for different period of time, therefore, they had varied teaching experiences.

\subsection{Procedure}

The student and teacher participants of this study were selected from a secondary school in Ipoh Perak. First, the consent of the Principal of the secondary school was obtained for the research to take place in the school. The Principal gave a list of teachers' names that were teaching English language in the school and arranged a meeting between the teachers and the researchers after schooling period. During the meeting, a thorough explanation was provided on the questionnaire to the teachers and the questionnaires were distributed to the teachers. They were given 30 minutes to fill out them. The objectives of the research were also explained to the teachers to give a wider perspective to them about the study. The questionnaire consisted of 3 parts, namely conventions, and punctuation, and language use. Each of these parts contained 9 Likert-scale items (1= Always. 2= Sometimes and 3= Never) and the teachers were supposed to circle the suitable answers.

The student participants were randomly selected from some available classes. One day after the meeting for filling out the questionnaire, all 10 teachers distributed the essay examination papers among their students. Examination sheets were given to the students in classrooms to write the essays immediately. They were given 40 minutes to write the essay. Their essays were immediately collected. Then, the essays were examined by the researchers to check for 
possible intended errors and also to see whether these errors can match with teachers' perceived feedbacks on students' writing errors.

The researchers assessed students' essays for any writing errors in conventions, punctuation, and language use. The 10 questionnaires were also analyzed to compare the students' errors in the essays with teachers' feedbacks on students' writing errors.

\section{Results}

This chapter addresses the answers and results found in this research through the questionnaire and sample essays according to research objectives and questions.

\section{1 Analysis of Research Questionnaire}

The following tables and figures have been analyzed carefully to present the teachers' opinion on every single writing problem which conveys, according to this study, nine sub-categories in every single area of writing (i.e. conventions, punctuation, and the language use) that were stated in the questionnaire. Charts and tables in the following represent the results of the analysis.

\subsubsection{Conventions:}

Table 1 represents the complete list of items for conventions and all 10 teachers' scores on the related items. It can be seen that all teachers believed that their students' writing are only sometimes clear. In other words, students' writings are not always clear. In addition, the majority of participated teachers believed that students have problems in proper use of lines in the paper, beginning of the sentences, writing complete sentences, and their writing length.

Table 1. Teachers Feedback on Students' Convention items

\begin{tabular}{|c|c|c|c|}
\hline ITEMS & ALWAYS & SOMETIMES & NEVER \\
\hline Your students' handwritings are clear. & 0 & 10 & 0 \\
\hline Your students make proper use of lines in the paper. & 3 & 7 & 0 \\
\hline Your students leave white spaces between words. & 6 & 3 & 1 \\
\hline Your students' sentences go from left to right. & 6 & 4 & 0 \\
\hline Your students' sentences begin in easy. & 1 & 6 & 3 \\
\hline Your students write complete sentences. & 2 & 7 & 1 \\
\hline Your students' words/sentences go from right to left & 1 & 3 & 6 \\
\hline Your students write to small or too large. & 3 & 7 & 0 \\
\hline Your students use cursive writing. & 1 & 5 & 4 \\
\hline
\end{tabular}

Figure 1 shows teachers' feedbacks on conventions errors of students in their writing using a bar chart to make it easy to compare the occurrence of errors. 


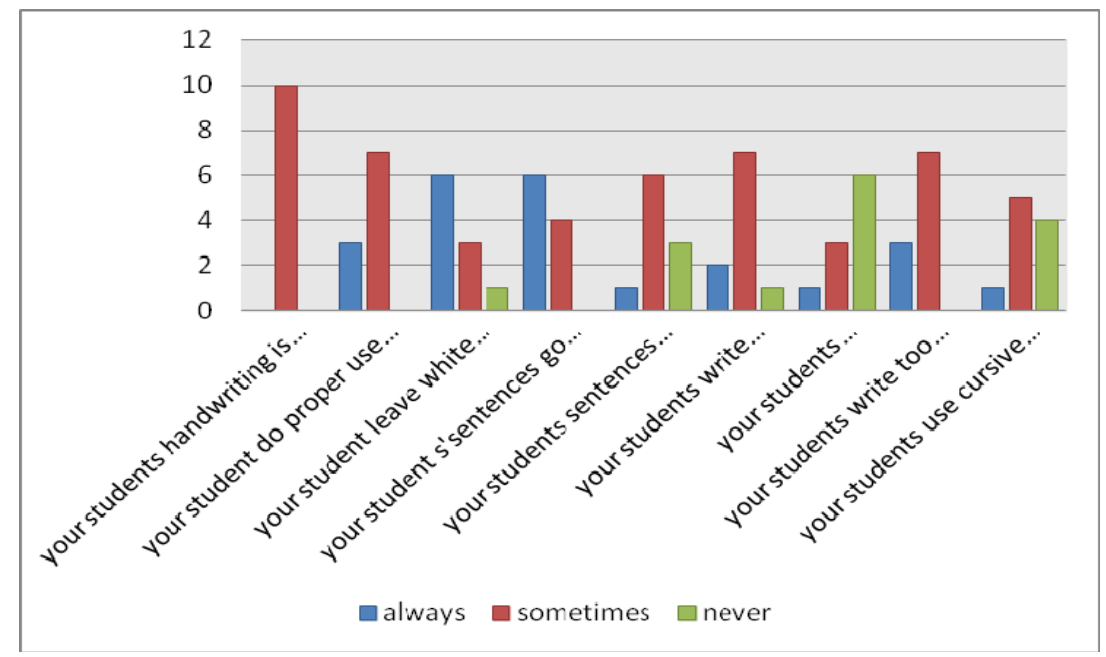

Figure 1. Teachers Feedback on Students’ Occurrence of Convention Errors

\subsubsection{Punctuation:}

Table 2 depicts the complete list of items for punctuation and teachers' scores on them. Students also face punctuation problems in essay writing. According to the teachers' responses, students usually have problems or confusion in using question mark, colon or semicolon, apostrophes, and commas while writing essays. It is necessary for teachers to take punctuation problems of students into account, especially when they are correcting students' essays.

Table 2. Teachers Feedback on Students’ Punctuation Items

\begin{tabular}{|c|c|c|c|}
\hline ITEMS & ALWAYS & SOMETIMES & NEVER \\
\hline Your students use a full stop at the end of each sentence. & 8 & 1 & 1 \\
\hline Your students use a question mark at the end of each question. & 2 & 8 & 0 \\
\hline Your students use an exclamation. & 1 & 6 & 3 \\
\hline Your students know the proper use of commas. & 1 & 9 & 0 \\
\hline Your students always confuse between the full stop and comma. & 0 & 8 & 2 \\
\hline Your students confuse with colon and semicolon. & 6 & 3 & 1 \\
\hline Your students use question marks in dialogues. & 3 & 7 & 0 \\
\hline Your students use commas between words in a list. & 3 & 7 & 0 \\
\hline Your students use apostrophes in contractions and possessives. & 1 & 8 & 1 \\
\hline
\end{tabular}

Figure 2 shows teachers' feedbacks on punctuation problems of their students' writing in a bar chart according to the occurrence of errors from always to never scale. 


\section{Macrothink}

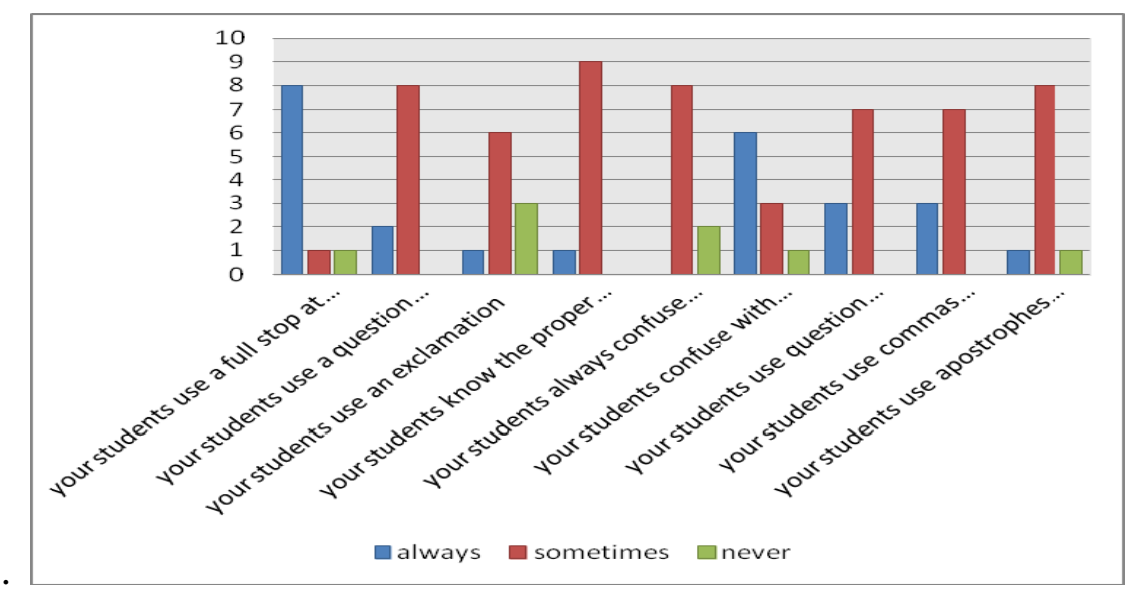

Figure 2. Teachers’ feedback on Students’ Occurrence of Punctuation Errors

\subsubsection{Language Use}

Table 3 represents the complete list of items for language use and its score on teachers' feedbacks. They agree that although their students are able to use synonyms/antonym and accurate grammatical structures in their essays, they sometimes struggle using appropriate language. The students also often use L1 words and Bahasa Malay sentence patterns in their sentences and writings. Students are also able to use SVO (Subject + Verb + Object), SP (Subject + Predicate) and SVA (Subject + Verb + Adverbial) patterns with minimal errors. Compared with the two previous aspects of writing, it is seen that teachers report more error occurrence in language use. To sum up, students need language support with basic vocabulary items and grammatical structures.

Table 3. Teachers Feedback on Students’ Language Use Items

\begin{tabular}{|c|c|c|c|}
\hline ITEMS & ALWAYS & SOMETIMES & NEVER \\
\hline Your students use appropriate language. & 0 & 8 & 2 \\
\hline Your students use synonyms/antonym of words they write a lot. & 0 & 9 & 1 \\
\hline Your student use L1 words in their sentences/writings. & 1 & 8 & 1 \\
\hline Your students use SVO/SP/SVA patterns correctly. & 1 & 9 & 0 \\
\hline Your students use the correct form(s) of the verb/words. & 1 & 8 & 1 \\
\hline Your students use Bahasa Malay sentence patterns. & 2 & 5 & 3 \\
\hline Your students need language support/struggle with the basic & 3 & 6 & 1 \\
\hline vocabulary. & 0 & 9 & 1 \\
\hline Your students use accurate grammatical structures. & 3 & 6 & 1 \\
\hline
\end{tabular}

Figure 3 demonstrates teachers’ feedbacks on Language use aspect in their students’ writing. 


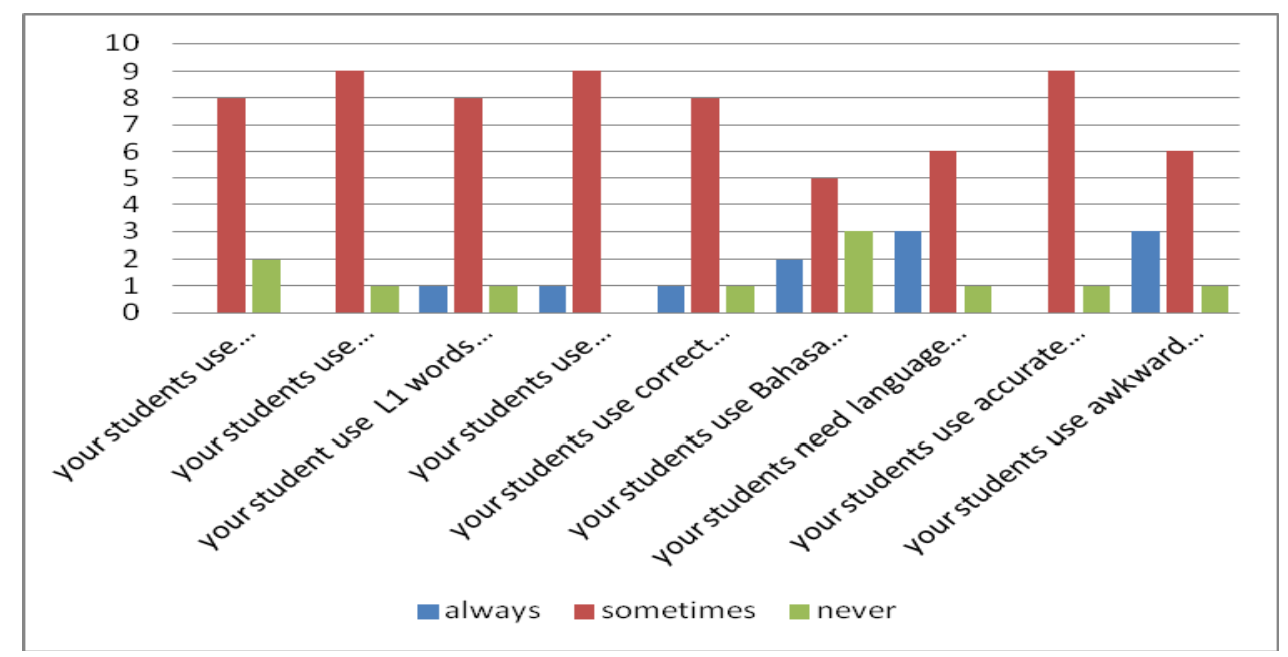

Figure 3. Teachers’ feedback on Students’ Occurrence of Language Use Errors

\subsection{Analysis of Students’ Writing Samples}

Students' essays were analyzed and marked by the researchers to see how many errors they have made based on the three related aspects (i.e. conventions, punctuation, and language use). Table 4 depicts the total number of students' errors on conventions, punctuation, and language use in their essay examinations.

Table 4. Total Writing Errors of Students on Conventions, Punctuation, and Language Use

\begin{tabular}{|c|c|}
\hline Items & Total errors of all 30 students \\
\hline Conventions & 52 \\
\hline Punctuation & 65 \\
\hline Language use & 123 \\
\hline
\end{tabular}

According to table 4 and the 3 intended aspects that were considered to analyze students' essays, it is represented that the students have problems in conventions, punctuation, and more specifically in language use. As it can be observed, with an approximate calculation, the highest error which is done by students in essay writing is language use, whereas the lowest is conventions. Punctuation holds the second position in writing errors among the 3 intended errors. This is also in line with the teachers' experienced feedback on the frequency of students' writing errors in the intended aspects. Figure 4 displays all three types of errors in students' writing samples. 


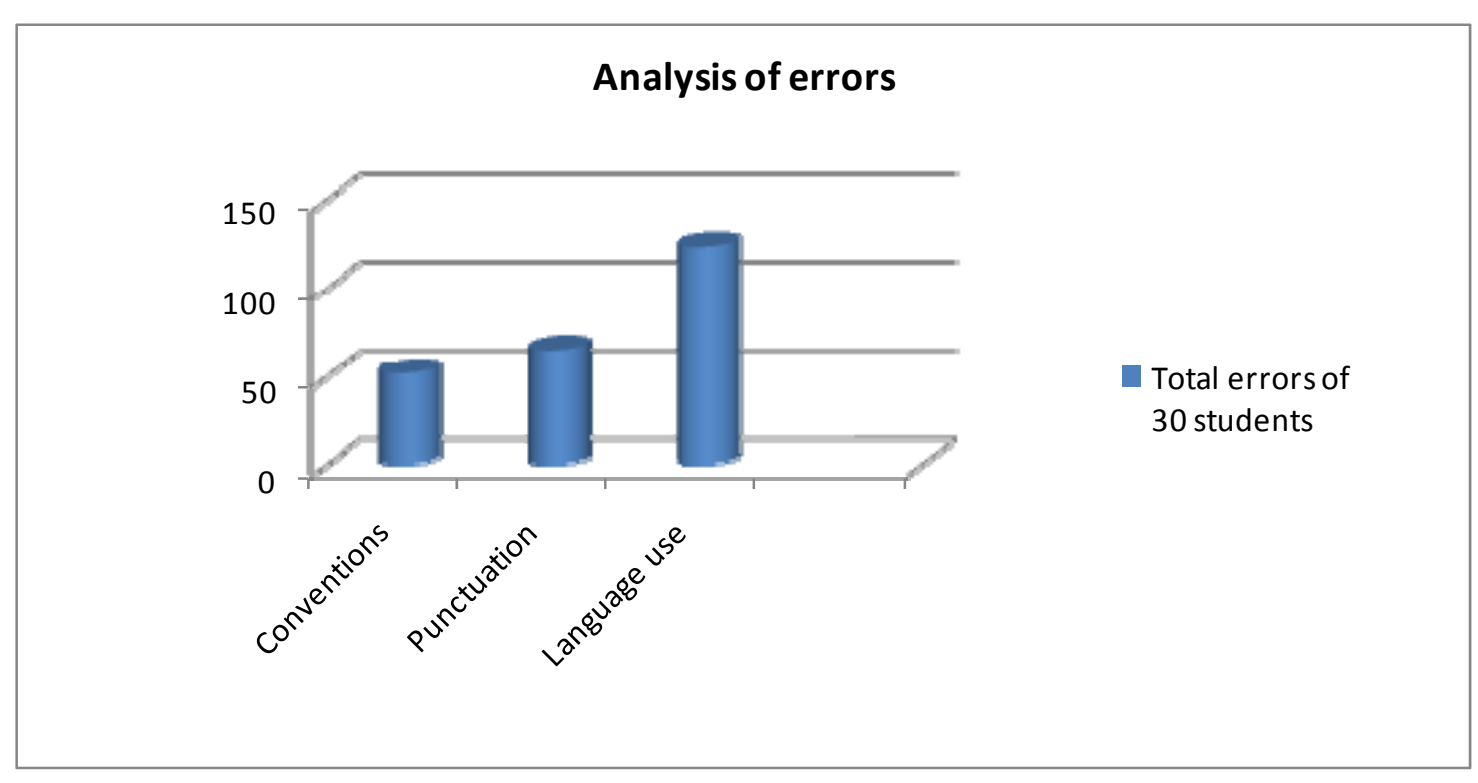

Figure 4. Students Writing Problems on Conventions, Punctuation, and Language Use

\section{Conclusion}

Taking into account the writing complications and coming up with applicable solutions to writing problems can undoubtedly influence ESL writing proficiency and bring desirable improvements. This study is conducted based on several researches carried out regarding students' writing skill and writing problems in ESL context. The focus of this study has been Malaysian ESL secondary school students' writing errors and teachers' feedbacks on such errors. The writing error items studied in this research were Language use, conventions, and punctuation. The findings of this study confirmed the previous research (Maros, Hua, and Khazriyati, 2007; Musa, Lie, \& Azman, 2012) reporting ESL students 'writing problems in different areas, particularly in language use. It can be concluded from the findings that ESL students need more improvement on English language proficiency and language use. Then, they require training on punctuation and writing conventions respectively. Additionally, teacher training should also be taken seriously into account in order to improve and develop ESL students' language proficiency in general and writing skill in particular.

\section{Suggestions}

The following suggestions and remedies have been proposed by some experienced teachers and the researchers based on their experience to reduce the problems in conventions, punctuation, and language use.

\section{Suggestions}

- Writing classes must witness more practice than delivering lectures

- The teacher must explain the use of all the punctuation marks 
- The teacher must explain the rules of capitalization

- The teacher must engage the learners in memory/vocabulary games

- The teacher must motivate and encourage the learners before the actual writing

- The teacher must provide the language support on every single topic

- The teacher must act as a prompter to assist the student at times

- Students should be encouraged to do home assignment as much as possible

Remedial Exercises

\section{A. Conventions}

- Copy and dictation,

- Jumbled words exercise, and peer editing.

\section{B. Punctuations}

- Storytelling (melody of speech),

- Editing, and

- Loud reading with proper punctuation awareness

\section{Language use}

- Form and functions exercises,

- Sequence of tenses exercises, and

- Gap filling/story writing exercises.

Therefore, all ESL teachers are suggested to deeply give attention to their students' errors and practice innovated styles to face these complexities in writing classes. Further studies can also measure the effect of teachers' feedback and teaching style of writing errors changes.

\section{References}

Al-Khasawneh, S.M.F. (2010). Writing for Academic Purposes: Problems Faced by Arab Postgraduate Students of the College of Business. ESP World, 9(2), 28. retrieved from http://www.esp-world.info

Gue'nette, D. (2007). Is feedback pedagogically correct? Research design issues in studies of feedback on writing. Journal of Second Language Writing, 16, 40-53.

Hedgcock, J., \& Lefkowitz, N. (1996). Some input on input: Two analyses of student response to expert feedback in L1 writing. Modern Language Journal, 80(3), 287-308. http://dx.doi.org/10.1111/j.1540-4781.1996.tb01612.x

Hyland, K. (2003). Second Language Writing. Cambridge: Cambridge University Press. http://dx.doi.org/10.1017/CBO9780511667251 


\section{Macrothink}

Journal of Studies in Education

ISSN 2162-6952

2012, Vol. 2, No. 3

Leki, I. (1992). ESL composing: Strategies and perceptions. In B. Leeds (Eds.), Writing in a Second Language: Insights from First and Second Language Teaching and Research. Longman: Addison-Wesley.

Mourtaga, K. (2004). Investigating Writing Problems among Palestinian Students: Studying English as a Foreign Language, Bloomington, Indiana: AuthorHouse.

Musa, C.N., Lie, Y.K., \& Azman, H. (2012). Exploring English Language Learning and Teaching in Malaysia, Journal of Language Studies. 12(1), 35-51.

Nazim, M., \& Ahmad, J. (2012). Developing Writing Skills: A Practical Remedy of Common Writing Problems among Students of Writing Skills Courses at Preparatory Year. Journal of Language in Indi, 12(3), 348-360.

Pak-TaoNg. P. (2003). Effective Writing: A Guide for Social Science Students, the Chinese University of Hong Kong.

Ramaprasad, A. (1983). On the definition of feedback. Behavioral Science Journal, 28(1), 4-13.

Tan, E.K., \& Miller, J. (2008). Writing in English in Malaysian High Schools: The Discourse of Examinations, England: Routledge.

Tony, S., \& Matsuda, K. P. (2001). Land Mark Essays: On EL Writing, New Jersey, Lawrence Erlbaum Associates, Inc.

Voon Foo, C. T. (2007). The Effects of the Process-Genre Approach to Writing Instruction on the Expository Essays of ESL Students in a Malaysian Secondary School. Unpublished PhD thesis, Universiti Sains Malaysia. Penang, Malaysia.

Yu, H.J. (2008). Interactional Structure in the Writing Process: A Comparison of Three ESL Writing Classes, Unpublished PhD thesis, Arizona State University, U.S.A.

Zamel, V. (1983). The composing process of advanced ESL students: Six case studies. TESOL Quarterly, 17(2), 165-187. http://dx.doi.org/10.2307/3586647 